\title{
The Purpose of "Correction" in the Russian Criminal and Criminal and Executive Law
}

\author{
Epikhin Alexander Yuryevich ${ }^{1}$, Zaitsev Oleg Aleksandrovich ${ }^{2}$, Tasakov Sergei Vladimirovich ${ }^{3}$, Nechaeva Elena \\ Vladimirovna $^{3}$, Mishin Andrey Viktorovich ${ }^{1} \&$ Aliyeva Gulnar Isaevna ${ }^{1}$ \\ ${ }^{1}$ Kazan Federal University, Russia \\ ${ }^{2}$ The Institute of Legislation and Comparative Law, Government of the Russian Federation, Russia \\ ${ }^{3}$ The Federal State Budgetary Educational Institution of Higher Education, Chuvash State University by I.N. \\ Ulyanov, Russia \\ Correspondence: Epikhin Alexander Yuryevich, Kazan Federal University, Russia. E-mail: doc@epihin.ru
}

Received: June 9, 2019

doi:10.5539/jpl.v12n5p6
Accepted: August 25, $2019 \quad$ Online Published: August 31, 2019

URL: https://doi.org/10.5539/jpl.v12n5p6

\begin{abstract}
The process of carrying out (serving) a criminal punishment in the form of imprisonment according to the Russian criminal and penal law provides for isolation of the convicted person, limitations of rights and certain freedoms, as well as using corrective measures to change the criminal orientation of that person towards positive law-abiding behavior. According to penal law, the corrective process is being implemented by carrying out the main measures of corrective action, which the law lists as: regulated conditions, socially useful labor, educational work, general and professional education, and social influence.

Currently the penal system sees a general trend of reducing the total number of imprisoned persons. According to the statistics by the Federal Penitentiary Service of Russia, 880 thousand people were serving a prison sentence in 2010, 550 thousand people in 2016, as of 1 June 2018 that number was 520.5 thousand people, and as of 1 May 2019 it was 552,188 persons. In the recent years, the number of prisoners tends to stay on the same level. These numbers testify to the continued humanization of the criminal and penal policy of the Russian Federation, as well as to the results of applying corrective actions to those sentenced to imprisonment.
\end{abstract}

Keywords: criminal punishment, correction of convicts, criminal law, types of punishments, goal of criminal punishment

\section{Introduction}

Russian and foreign researchers continue a discussion regarding various aspects of determining the definition and content of the goals of criminal punishment. One of those aspects is concerned with the problem of determining the content of corrective action for inmates as an independent goal of the criminal punishment under Russian criminal and penal law.

There are differing and sometimes opposing opinions and suggestions in the subject area. The most radical is perhaps the suggestion of $\mathrm{N}$. A. Belyayev to "abolish the "goal of correction" as a criminal law category", and replace it with "social functions" that will reflect the real goal of criminal punishment". T. P. Butenko also states that correction of an inmate is not a term in the criminal law.

We note that the word "to correct" is defined in dictionaries as eliminating an error, deficiency or defects.

Unfortunately, criminal law does not describe the content of the notion of "goal of punishment". In criminal law theory, it is based on its philosophical interpretation. M. D. Shargorodsky linked the goals of criminal punishment with the actual result that the state sets as its goal. T. P. Butenko stated an almost identical opinion, suggesting to define them as the "social result that the state is aiming for". L. L. Kruglikov defines the goal of punishment as the "...final, imaginable result that the state aims to achieve". Obviously, correction of inmates as one of the criminal law goals is a topic for discussion and causes some differences in its understanding and legal regulation. 


\section{Methods}

The dialectical method is the methodological basis of this study. The following special methods of cognition have been used: logical law method; comparative, historical, sociological, systematic structural method, statistical method, analysis and synthesis, legal modeling.

The goal of this study is to analyze the content of the goal of "correction of inmates" in the criminal and penal law applied to convicts serving a sentence in the form of imprisonment.

\section{Results and Discussion}

Over 20 years have passed since the Correctional Code of the Russian Federation took effect. The social, political and economical situation in the country has changed. Crime has changed; one of those changes is the increasing social danger of organized and professional crime. This negative tendency forces the government to improve its corrective system for prisoners.

The penitentiary science analyzes various aspects of the main methods of corrective action stated in the Correctional Code of the Russian Federation. Studies have analyzed various sides of the practical use of corrective action in penitentiary institutions; some researchers suggest expanding the main corrective actions listed in the Correctional Code of the Russian Federation, and develop criteria for estimating the degree of correction of inmates.

The legal problems concerning inmates attract attention of Russian and foreign researchers, including those interested in ensuring safety of inmates as participants of criminal proceedings.

Despite multiple studies having been made, they have not found a proper theoretical ground for the classification of corrective measures that must be systematized and regulated by the Correctional Code of the Russian Federation.

We note one of the goals stated in Article 43 of the Russian Criminal Code, which is the correction of the convicted person. In our opinion, the process of correcting a person who has committed a crime has specific features and should differ from the criminal law goals. For that reason, the fact the correction is mentioned in Article 43 of the Criminal Code of the Russian Federation is somewhat doubtful.

The Criminal Code of the Russian Federation provides three goals of punishment: 1) restoring social justice; 2) correcting the convicted person; 3 ) preventing new crimes.

Therefore the legislators set a certain sequence of achieving these goals. The notion of the first (1) and last (3) goals was not defined in law. The second goal of criminal punishment, "correcting the convicted person", is defined in law. However, the existing interpretation of this goal causes many discussions and arguments, including regarding whether it is appropriate to define it in the Criminal Code and Correctional Code of the Russian Federation.

Article 9 of the Correctional Code of the Russian Federation specifies the notion of "correction of convicted persons". In accordance with Part 1, Article 9 of the Correctional Code, legislators define the correction of convicted persons as: "creating in convicted persons a respectful attitude to people, society, labor, norms, rules and traditions of human co-existence and stimulating the law-abiding behavior".

In other words, the convicted person should cease to have danger to society, and acquire the properties specified in this article of the Correctional Code, and in that case they may receive certain benefits while serving the sentence and may be released early.

The interpretation of the notion of "correction of the convict" which is specified in the law accentuates the personality of the criminal, rather than the criminal act itself. With regard to this, research literature provides an opinion of T. V. Minyazeva that punishment is a consequence of the crime, and not of criminality in general.

The goal of correction has a cross-sector character, because it is mentioned in both criminal and penal law. This was also the case in criminal law of the Soviet period.

V.S. Komissarov notes that the correction of a convicted person may not be limited to merely criminal law-based action; it comprises not only legal but also social correction of the convicted person, a certain transformation. T. F. Minyazeva believes that such division is superfluous. In her opinion, "the goal of correction of a criminal in penal law is viewed as a legal interpretation of the goal of correction in criminal law". Thus, she points out that they are identical. Nevertheless, regardless of where the goal is stated, this does not solve the problem of achieving that goal. 
First of all, setting the goal of correcting a convicted person is problematic because of the question of whether it is indeed possible to rebuild the social and psychological image of a criminal by using criminal, legal or penitentiary measures. Certainly this is possible in theory, but only in case of simultaneous and thorough corrective action on the personality. In this case, criminal punishment would only be a small part of such action.

The punishment itself cannot be used separately to solve the issue of correcting the convict. This is evidenced by the statistics that reflect the efficiency of criminal punishment. In 2016, 218,454 ex-convicts (more specifically, people who have a pending or outstanding conviction) were convicted again, or $30.9 \%$ of the total number of crimes; out of those, 3,865 were minors. In 2017, 213,354 ex-convicts (more specifically, people who have a pending or outstanding conviction) were convicted again, or $33.2 \%$ of the total number of crimes; out of those, 3,900 were minors.

The metric that indicates that the corrective goal was achieved or not achieved is the recidivism rate, which is $1 / 3$ of all registered crimes, and remains stably high. This shows insufficient efficiency of the punishment and prevention of new crimes. With these numbers, it is difficult to claim that the goal of criminal punishment is to correct the convict.

In that regard, let us note I. I. Karpets's suggestion that the real correction should be analyzed not as a goal of criminal punishment, but as a specific prevention and forming a strong motivation for the convicted person not to commit new crimes.

One of the important aspects of the problem of achieving the corrective goal is its attainability. The Criminal Code of the Russian Federation does not specify that the goal of correcting the convict only relates to imprisonment. This means that it equally applies to all types of criminal punishment, which has to be recognized as an important circumstance. However, T. F. Minyazeva asks a fair question: "how can the number of hours of community service or a certain amount of a fine create respect to other people, society, labor, rules and norms of human co-existence etc.", or in other words, correct a person.

The above lets us conclude that the goal of correcting the convicted person, if it is equally defined for all types of punishments, is not attainable, which significantly reduces its value. With that understanding, it is obvious that correcting the convict is not realistic.

Consequently, we must search for a solution of the above problem. One of the solutions, in our opinion, could be to fully exclude the term "correction" from the Criminal Code and the Penal Code of the Russian Federation, and replacing it with a definition of "corrective action", and to abolish the wording in Part 1, Article 9 of the Penal Code of the Russian Federation that contains an archaic and unrealistic definition of social correction as a goal of punishment.

Currently criminal and penal law studies contain two main approaches to defining the notion of correction: 1) moral correction of convicts, and 2) legal correction of convicts.

Moral correction means changing the negative value orientations of convicts into positive behavior. Legal correction means reorienting a person from criminal behavior to law-abiding behavior.

Other researchers also pointed out the multi-faceted nature of correction. Professor I. S. Noy understood moral correction as "such transformation of the convict's personality that they would not commit a new crime not because of the fear of punishment, but because it would be against their new views and beliefs".

S. V. Tasakov defines morality as "...a combination of norms (moral norms) that define the behavior of an individual as virtuous depending on the existing customs, traditions and principles of human co-existence.

We believe that by joining and continuing the discussion about the process of correcting a convict, we should primarily look at the moral correction. Importantly, without a positive change in a person's conscience and his moral beliefs, it is impossible to achieve a legal correction.

\section{Summary}

Based on the study we conducted, the following conclusions can be made:

1) Given the above circumstances, we suggest replacing the term "correction of a convict" with "corrective action". For that purpose, we provide our definition of corrective action, and therefore suggest amending Part 1, Article 9 of the Penal Code of the Russian Federation as follows: "Corrective action is a process aimed at changing the convicts' negative value orientations that cause the commission of crimes with positive beliefs, and motivating the convict for law-abiding behavior and reintegration into the society". 
2) This notion of "corrective action" should be regulated initially through the Criminal Code of the Russian Federation, and later in penal law.

\section{Conclusions}

The above deliberation regarding the goal of punishment in criminal and penal law, as well as our suggestion to adjust the term "correction" itself and its definition, may modify the contemporary approach to Russian criminal law in general, and to the penitentiary system in particular. A transition is needed from declarative regulations that do not contribute to efficient reduction of crime, to actionable instructions; a deep transformation of Russian criminal and penal law needs to be expedited.

\section{Acknowledgements}

The work is performed according to the Russian Government Program of Competitive Growth of Kazan Federal University.

\section{References}

Anisimkov, V. M. (Ed.). (2001). Penal law: a course of lecture. Saratov: SGAP.

Belyayev, N. A., Glistin, V. K., \& Orekhov, V. V. (Eds.). (1992). Modern criminal law. The problem of crime and punishment. Saint-Petersburg.

Boyd, W. (2015). Force-feeding prisoners is wrong. American Medical Association Journal of Ethics, (10), 904-908. https://doi.org/10.1001/journalofethics.2015.17.10.ecas2-1510

Brief characterization of the penal system. Retrieved from http://fsin.su/structure/inspector/iao/statistika/Kratkaya\%20har-ka\%20UIS/

Butenko, T. P. (2014). Correction of convicted persons as a goal of punishment in criminal and penal law. In the collection: Politics and Law. Bulletin, Blagoveshchensk.

Dingle, J. (2000). Invisible crime-deterrent systems make for friendly facilities. Facilities Design \& Management, (2), 20-21.

Epikhin, A. Y. et al. (2016a). Protection by the government and security support for the parties of modern criminal process in Russia: Problems and perspectives. Journal of Legal, Ethical and Regulatory Issues, 19.

Epikhin, A. Y. et al. (2016b). Protection of the Witnesses and Victims: International Legal Acts, Legislation of some States and the Modern Russian Legislation. Journal of Advanced Research in Law and Economics, $7(2), 313-322$.

Epikhin, A. Y. et al. (2017). Problem of Definition of Personal Security in the Modern Russian Criminal Procedure. Journal of Advanced Research in Law and Economics, 7(6), 1539-1545.

Epikhin, A. Y., Zaytsev, O. A., Tasakov, S. V., Nechaeva, E. V., \& Mukhametshin, T. R. (2018). The Correctional Process in Russian Penitentiary Institutions. The Journal of Social Sciences Research, 1, 183-186.

Ferri, E. (2005). Criminal Sociology. Compiled and foreword by V. S. Ovchinsky. Moscow: Infra M.

Inogamova-Khegay, L. V., Komissarova, V. S., \& Raroga, A. I. (2015). Russian criminal law: 2 volumes. Volume 1. General Part: textbook. (4th ed.). supplemented and reworked. Moscow: Prospekt.

Karpets, I. I. (1973). Punishment. Social, legal and criminological issues. Moscow.

Khrabrova, E. V. (2015). Organizing educational work with underage convicts in the social environment of a juvenile correctional facility. Institute Herald: crime, punishment, correction, 4(32), 97-101.

Korotkikh, N. N. (2015). Taking into account the personality of a person convicted of multiple crimes for the purpose of parole. Criminology Journal of Baikal State University of Economics and Law, 9(3), 440-446.

Kruglikova, L. L. (Ed.). (2013). Criminal Law of Russia. General Part: textbook. Moscow: Prospekt.

Kuznetsov, S. A. (Ed.). (2008). Big Thesaurus of Russian Language. Saint-Petersburg: Norint.

Minyazeva, T. F., \& Dobryakov, D. A. (2016). Correction of a criminal as the goal of punishment. Eurasian Law Practice, 2(21), 63-66.

Nechaeva, E. V. (2006). Implementing a progressive penitentiary system in a detention facility. Legislation and Law, (7), 18-19.

Noy, I. S. (1973). Essence and functions of criminal punishment in the Soviet state. Saratov: Saratov University Publishing House. 
Papora, A. I. et al. (Eds.). (2012). Criminal Law Action: a monograph. Moscow: Prospekt.

Schedrin, N. V. (2011). Concept, kinds and limits of security measures. Journal of the Siberian Federal University. Series: Humanitarian sciences, (1), 112-118.

Sherman, L. (1995). Public regulation of private crime prevention. Annals of the American Academy of Political and Social Science, (1), 102-113. https://doi.org/10.1177/0002716295539001008

Tasakov, S. V. (2008). Moral basics for criminal law regarding crimes against the person. Moscow, R. Aslanov "Legal Center Press" Publishing House.

\section{Copyrights}

Copyright for this article is retained by the author(s), with first publication rights granted to the journal.

This is an open-access article distributed under the terms and conditions of the Creative Commons Attribution license (http://creativecommons.org/licenses/by/4.0/). 